\title{
The 8200 calBP climate event and the spread of the Neolithic in Eastern Europe
}

\author{
Marianna A. Kulkova ', Andrey N. Mazurkevich 2, Ekaterina V. Dolbunova ${ }^{2}$ \\ and Vladimir M. Lozovsky 3 \\ 1 Herzen University, St. Petersburg, RU \\ kulkova@mail.ru \\ 2 The State Hermitage Museum, St. Petersburg, RU \\ 3 Institute of the History for Material Culture, St. Petersburg, RU
}

\begin{abstract}
At 8200 calBP, the beginning of the Atlantic period, there was a drastic change from warm and humid climatic conditions to cold conditions. The abrupt cooling at 8200 calBP has been documented in different parts of Europe. In western, and some parts of southern, Europe, this event was a trigger for new forms of economy and migrations of groups of Neolithic farmers. This paper considers the different ways in which ceramic traditions developed in eastern Europe in the steppe, steppe-forest and forest zones as a result of the rapid climate changes at about 8200 calBP.
\end{abstract}

IZVLEČEK - V času okoli 8200 calBP, to je na začetku obdobja atlantika, je prišlo do korenite spremembe klime, od toplih in vlažnih pogojev do ohladitev. Nenadna ohladitev v času 8200 calBP je dokumentirana v različnih delih Evrope. V zahodni in v delu južne Evrope je dogodek sprožil nove oblike gospodarstev in preseljevanje skupin neolitskih poljedelcev. V članku razpravljamo o različnih oblikah razvoja keramičnih tradicij na stepskih, gozdno-stepskih in gozdnih območjih v vzhodni Evropi kot posledico te hitre klimatske spremembe v času 8200 calBP.

KEY WORDS - rapid climate change; Neolithic; pottery; Eastern Europe

\section{Introduction}

Until now, the Holocene has been considered as an interstadial period, with stable climatic conditions. According to Richard Tipping et al. (2012) the old paradigm of slow, gradual change (Lamb 1977; 1995) has been replaced by one in which change can be described as abrupt, occurring over short timescales of centuries or less, separated by comparatively long periods of quasi-stasis (Mayewski et al. 2004 ). The $8.2 \mathrm{ka}$ years event was part of a climatic cooling period from $c$. 8600 to 8000 calBP (Rohling, Pälike 2005; Thomas et al. 2007; Walker et al. 2012) that interrupted the long-term trend of rising earlyHolocene temperatures. The event lasted approx. 160 years (Daley et al. 2011; Kobashi et al. 2007). It has been detected as a marked cold snap in multiple paleoclimatic records from the Greenland ice cores and a variety of sedimentary records, espe- cially in northern Europe (Alley, Ágústsdóttir 2005; Seppä et al. 2007; Thomas et al. 2007; Walker et al. 2012). The abrupt cooling at 8200 calBP has also been documented in different parts of Europe. This evidence includes the stratigraphic record of lake drainage (Barber et al. 1999), reconstructions of sea level rises ( $L i$ et al. 2012; Tornqvist, Hijma 2012), and geochemical reconstructions of freshwater discharge from the Hudson Strait and northwest Labrador Sea (Carlson et al. 2009; Hoffman et al. 2012). The last global syntheses of proxy data around 8200 calBP were published recently (Wiersma, Renssen 2006; Morrill, Jacobsen 2005; Rohling, Pälike 2005; Morill et al. 2013). There are fewer data available for Eastern Europe, and they are based mainly on data of pollen analysis. The high-resolution pollen diagram focusing on the $8400-7700$ calBP interval in- 
dicates that the taxa with the most marked decline were Alnus, Corylus and Ulmus. In deposits from lakes located in Finland, the pollen analysis also registered abrupt climatic cooling at 8200 calBP (Sarmaja-Korjonen, Seppä 2007; Seppä 2004; Veski et al. 2004). The end of this event is reflected as a sudden change between $c .8075$ calBP and $c .8050$ calBP, when the pollen proportions of Alnus (10\%), Corylus (2\%) and Ulmus (1.5\%) increase to $13 \%, 4 \%$ and $2.5 \%$, respectively. Some evidence for this event was obtained on the basis of geochemical analyses of lake deposits and radiocarbon date distributions for sites in the north-western part of Eastern Europe (Kulkova et al. 2015).

At the beginning of the Atlantic period, the warm and humid climatic conditions changed to cold conditions drastically at 8200 calBP. It was the first considerable cooling after the Younger Drias. The temperature fell to $0.5-1.5^{\circ} \mathrm{C}$ in Europe, Greenland, Northern America, Asia, Northern Africa and the eastern part of northern Atlantic Ocean (Seppä, Poska 2004; Rasmussen et al. 2006; Vinther et al. 2006; Morrill et al. 2013). According to the data of Ane Wiersma et al. (2006), the cooling was accompanied by dry climatic conditions. However, a dry climate prevailed in northern and southern Europe (Magny et al. 2003). The humid climate in this period has been registered in several places in the middle latitudes of Europe, approx. between $43^{\circ}$ and $50^{\circ}$ north.

One of the main factors in climatic change is variation in solar activity (Bond et al. 2001; van Geel et al. 2004). There is a wealth of empirical evidence to support this theory, mostly based on isotopic data. The model experiments of Hugues Goosse et al. (2002) showed that variations in solar radiation could cause variations in thermohaline convection in oceans, as well as the polar atmospheric flows in both of hemispheres. These processes (Lamy et al. 2010; Magny et al. 2003; Mullins, Halfman 2001) weaken African and Asian monsoons and result in a fall in temperature and a thermal contrast between terrestrial and oceanic air masses. On the other hand, the increase and drift of Westerlies regulates the humidity balance in low and middle latitudes in response to changes in the thermal gradient between high and low latitudes. The territories affected by Westerlies are characterised by more humid conditions (Bush 2005).

The sensitivity of ecosystems to abrupt climate changes in the past has been considered by different scholars (Hofmann 2000; Birks, Ammann 2000; Dui- gan, Birks 2000; Williams et al. 2002; Baldia 2013). The climatic changes caused by the abrupt cold event, most notably the cooling in the Northern Hemisphere and an increase in aridity in the lower latitudes are thought to have affected human populations in many parts of Europe and beyond ( $c f$. Binford 2001; Dincauze 2000; Kelly 1995). The coincidence in the timing of this hemispheric-scale abrupt climate change or a rapid climatic change (RCC) (Bond et al. 1997; Mayewski et al. 1997; 2004) with transformations in prehistoric societies and economies in north-western Europe has been considered elsewhere (Berger, Guilaine 2009; Berglund 2003; Turney et al. 2006; Karlen, Larsson 2007). The environmental changes were reflected in the records in various ways that are determined by such things as the severity of the effects of the changes on the ecosystem, the readiness of any given group to adapt, and the threat to group territory, as well as migrations, conflicts, and technological changes (see Manninen 2014). The demographic collapses caused by such crises and the following social and economic reorganisation can therefore be expected to be reflected in rapid changes in the record (Riede 2009).

The warm and humid climatic conditions at the beginning of the Holocene, the environmental changes, the increasing of availability and the diversity of food resources could have been factors in social transformation, such as an increase in population density (Adger et al. 2012; Gronenborn 2009; Munoz et al. 2010; Riede 2009; Robinson et al. 2013). One of these events was the development of Mesolithic societies, whereas the formation of Mesolithic groups occurred probably during a cold climatic period. The transition from the Paleolithic to Mesolithic attributed to the Younger Drias period resulted in the complication of social structures, the occupation of new territories and the diffusion of small, independent Mesolithic groups over considerable distances (Bell, Walker 2005; Bassetti et al. 2009). In western and some parts of southern Europe, the abrupt cold event at $8.2 \mathrm{ka}$ BP could have triggered new forms of economy, such as the Neolithic, and also triggered the migration of groups of Neolithic farmers (Berger, Guilaine 2009; Weninger et al. 2006; Budja 2007). In the steppe and forest zones of Eastern Europe, these processes are not so clearly manifested.

\section{The 8200 calBP climate event and the Neolithic population dispersal}

A warm and humid monsoon climate prevailed in North Africa at the beginning of the Holocene, favourable to savannah with numerous lakes. The co- 
oling and decreasing of African monsoons at 8200 calBP caused dry climatic conditions. Some authors (e.g., Brooks et al. 2005) suggest that this period was a key point in the development of cattle pastoralism in the Sahara. Increased aridity is believed to have played a key role in encouraging the integration of cattle herding with existing hunting and foraging systems (Holl 1998; Hassan 2002). The exploitation of mountain pastures for goat and sheep grazing (possibly developed first in western Asia) was a result of drier conditions in the foothills of Libya. In this period, the dispersal and isolation of different cultural groups occurred all across the $\mathrm{Sa}$ hara. These groups migrated to unknown territories in search of water and pastures. Subsequently, settlements grew up around water basins (Brooks 2006). The earliest settlements in the southern part of Egypt consisted of small groups engaged in cattle husbandry and pottery making (Wendorf, Shild 1998). The 8200 calBP climate event resulted in economic developments such as the appearance of small cattle and the growth of settlements with numerous fireplaces near large water basins.

According to Bernhard Weninger et al. (2006), the influence of the 8200 calBP event in Europe was greatest in Central Anatolia. The flourishing and well-established settlement at Catalhöyük-East was deserted quite abruptly around 8200 calBP. The site was reoccupied later, with a shift of the settlement by approx. 200m to a new position (ÇatalhöyükWest). This settlement shift marks the beginning of the Early Chalcolithic in Central Anatolia. The impact of climate event on prehistoric groups in Anatolia, Cyprus, Greece and Bulgaria has been considered by various authors (Staubwasser, Weiss 2006; Migowski et al. 2006; Weninger et al. 2006).

The 8200 calBP climate event was associated with the transition from the Pre-Pottery to the Pottery Neolithic era, which was marked by the collapse of the 'ritual economy' and agricultural PPN aggregation centres in the Levant (Budja 2007). As he noted, this climatic anomaly correlates chronologically with the process of the neolithisation in the Near East and south-eastern Europe. The collapse of the agricultural PPN aggregation centre in the Levant correlates with the cooling period and aridity. The initial agriculture in the Peloponnese and most of the Balkans predate the climate event at around 8150-7950 calBP, but the 'Neolithic package' (for more detail, see Cilingiroglu 2005) seems to have crossed the Danube and entered the southernmost region of the Pannonian Plain after the major climate fluctuations, and remained there for centuries (Budja 2007. 196-197).

Archaeological data and palaeoecological records suggest that the Neolithic acculturation process of the Carpathian Basin took place between approximately 8450-7450 calBP (Sümegi et al. 1998; Banffy, Sümegi 2012). It was a period of various transformations in Neolithic society.

\section{The spread of the Neolithic in Eastern Europe}

The process of neolithisation in Eastern and Southeastern, Central and Western Europe differed significantly. While the 'Neolithic package' distribution, 'agricultural frontiers' spread and 'demic diffusion' (Zvelebil 1998; Özdoğan 2001; Cilingiroğlu 2005; Budja 2013) mark it in the latter, in Eastern Europe, the main marker of the Neolithic process was pottery appearance without any other Neolithic components. However, some different components of the Neolithic package have been be found at the site Rakushechny Yar in the Low Don River region (90508450 calBP) (Belanovskaya et al. 2003) (Fig. 1). The earliest pottery and adobe architecture can be found in the Low Volga region (the Varfolomeevka site) (Yudin 2000). Also, the earliest pottery in this region appeared at sites in the Kairshak-Tenteksor group and Dzgangar-Varfolomeevka (9050-8650 calBP), and the Elshanian group in the Middle Volga River region (9150-7950 calBP) (Vybornov et al. 2008a; 2008b; 2010).

\section{The steppe and forest-steppe zones of Eastern Europe}

Rakushechny Yar in the Low Don River region One of crucial Early Neolithic sites in Eastern Europe, where almost all the components of Neolithic were found is at Rakushechny Yar (Belanovskaya 1995), located in the Lower Don River region (Fig. 1 ). Some types of pottery found at this site closely resemble ceramic types from other cultures of Eastern Europe. The artefact assemblage of this site is significant for understanding the process of neolithisation in the north-eastern Black Sea region. The radiocarbon dates, typological analogies of pottery, the specific bone industry, cattle husbandry, and adobe architecture reveal a similarity with Near Eastern sites, indicating an allochthonous character of the site (Belanovskaya, Timofeev 2003; Belanovskaya et al. 2003; Kotova 2002; Mazurkevich et al. 2012). Therefore, it should be considered a 'primary' centre for the development of some Neolithic ceramic 
traditions in the Low Volga and Don regions, the Upper Volga region, and the DneprDvina region.

The pottery from the Rakushechy Yar site has different shapes with flat bottoms (Fig. 2). Silt clay from deep and shallow water areas of the Don River basin was used for ceramic moulding. According to the petrographic analysis (Mazurkevich et al. 2013) the ceramic paste consists of clay loam tempered with sand and grog (dried and ground clay). The coil technique with stretching of strips of clay was used to make some of the earliest types of ceramics. The surface of the pottery was smoothed after scratching, or polished and smoothed without scratching. This type of pottery was undecorated.

Another ceramic type from these cultural layers has decoration; the decorated fragments make up about $9 \%$ of the ceramic collection. A variety of ornamentation can be observed here: simple compositions consisting of triangular signs, I-shaped motifs made with the impression technique, combing incisions, lines and denticulated impressions made with the 'rocking-chair' technique. Different types of raw clay deposits were used for making this type of pottery.

The radiocarbon dates on food crusts from the early types of pottery date this site to $c .8700-7840$ calBP.

\section{The Kairshak-Tenteksor and Dzgangar-Varfo-} lomeevka groups in the Lower Volga River region

According to Alexander Vybornov et al. (2012), sites of Kairshak complex existed on the semi-desert northern coast of the Caspian Sea from c. 8600 calBP onward. The pottery is characterised by flat bottoms, incisions as pottery decorations (after $V y$ - bornov 2008a) (Fig. 3), and is made of clay mixed with silt and shell. The local Mesolithic stone industry that persisted during the Neolithic period is characterised by artefacts such as geometric microliths in the form of segments and parallelograms. These Neolithic sites present a local type of neolithisation.

On the north-west coast of the Caspian Sea, the earliest sites of the Dzhangar type (Tu-Buzgu-Huduk I site) were dated to the first half of the $8^{\text {th }}$ milennium BP. The main innovation was the appearance of pottery (Fig. 3). The Kairshak and Dzhangar cultures influenced the development of the Orlovskaya cultural tradition in the Middle Volga River region around $c$. 8500-8400 calBP. The earliest Neolithic 

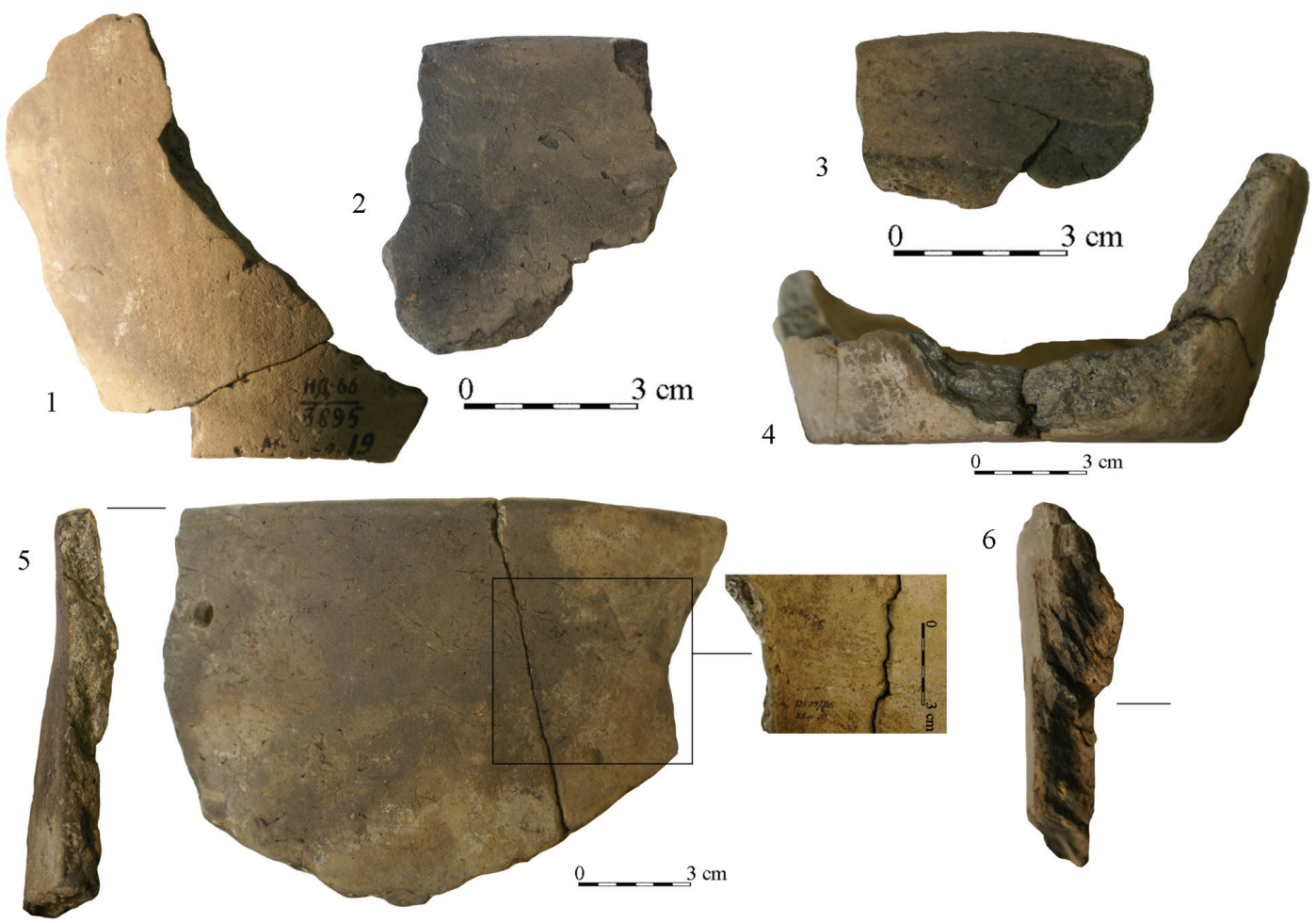

Fig. 2. The earliest (8700-7840 calBP and earlier) Neolithic pottery from the site Rakushechny Yar (bottom layers).

ceramics from the Djangar-Varfolomeevka sites were made from silt clay with sand and organic inclusions. The pottery has a closed shape with flat walls and flat or roundish bottoms. The decoration in the upper part was made with triangular and oval pins; the motifs consist of horizontal rows and horizontal zigzags (Vasilieva, Vybornov 2013; Vybornov 2008b).

\section{The Elshanian cultural group in the Middle Volga River basin}

The earliest Neolithic sites with 'Elshanian-type' pottery are located between the steppe and forest steppe zones in the Middle Volga River basin (Fig. 1). The most important sites of the early stage are the Ivanovo site on the Samara River and the Chekalino on the Sok River (Vybornov 2011). The pottery was made of plastic clay. It has pointed bases with impressions and incisions (Fig. 4) (Vasilieva, Vybornov 2013). The ${ }^{14} \mathrm{C}$ dating of different materials (such as foodcrusts, bones, pottery) from these sites dates the Elshanian ceramics to $c$. 8760-8000 calBP. The closest analogues to the typological and technological characteristics of Elshanian pottery were found on the eastern coast of the Caspian Sea and the Central Asian interfluves at the Uchaschy, Daryasay, and Dzhebel sites (Vybornov et al. 2012). Radiocarbon dates on the earliest Neolithic materials in Central Asia have the same age (Brunet et al. 2012). No sites in the Volga region of the steppe forest dating to $8350-8100$ calBP have been found (Vybornov et al. 2010).

At the end of the $8^{\text {th }}$ millennium BP, some Elshanian groups occupied the north-western Middle Volga region in the Sura River valley. The Vyunovo Ozero I and Utuzh sites, the Ozimenky site in the Moksha River basin (Vybornov 2011), the Imerka 7 site, the Plautino I and IV sites in the south-western part of the middle Khoper River, the Ustie Izlegoshy site in the Upper Don region, and sites of the Karamishevo type (Ivnitsa and Karamishevo 5 and 9 sites; see Smolyaninov 2012) date to this period.

Because of the 8200 calBP climatic event the groups which produced the 'Kairshak type' pottery moved from the northern Caspian shore towards the steppe region of the Volga River basin and the northwestern coast of the Caspian. They influenced the development of the Varfolomeevka and Dzhangar traditions in these regions. The characteristics of the pottery, the ornamentation techniques, and motifs support this. The process of neolithisation on the north coast of the Caspian and the Lower Volga regions was embedded in the period $c .8500-7900$ calBP (Vybornov et al. 2008b) (Fig. 1).

The climate in the steppe and forest steppe regions was more arid than today (Lavrushin, Spiridonova 
8540-8190 calBP
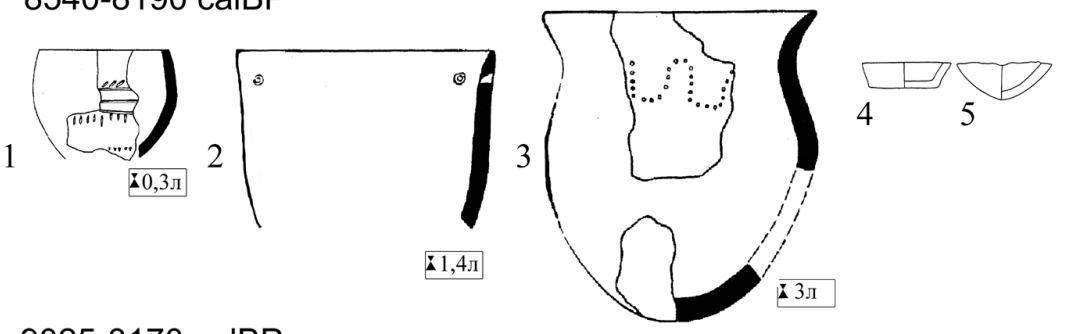

9025-8170 calBP
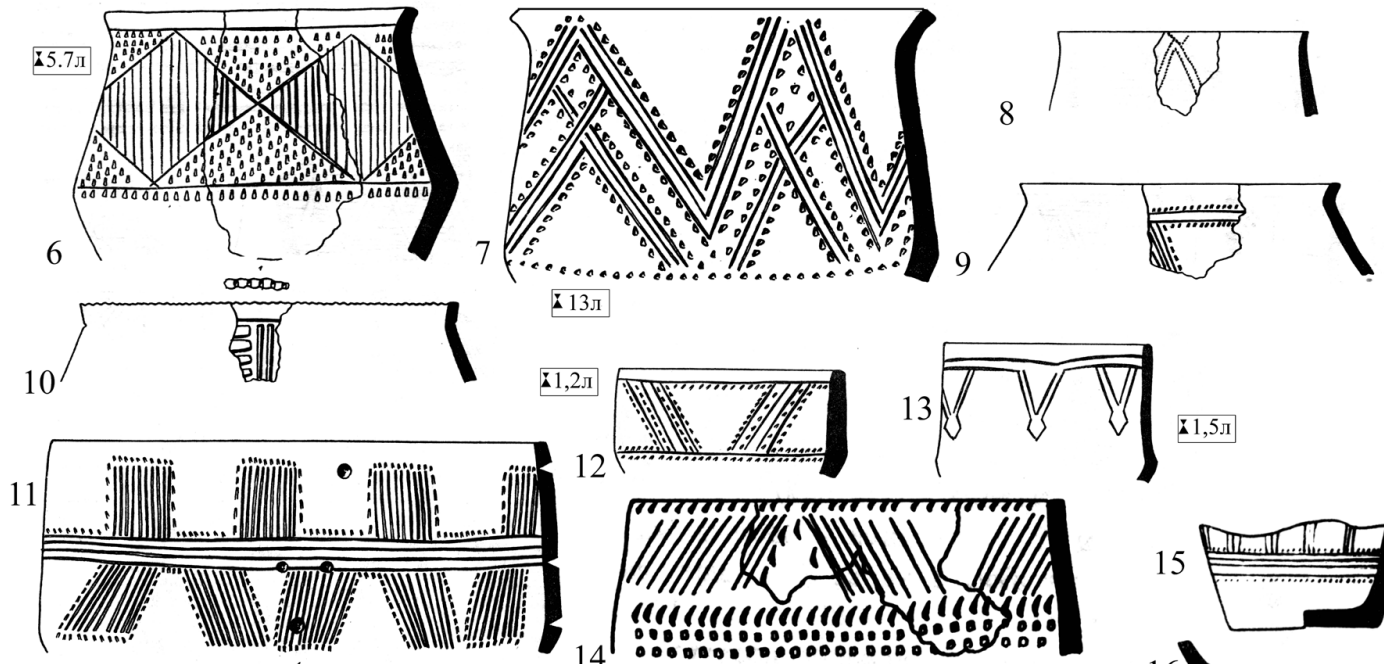

19
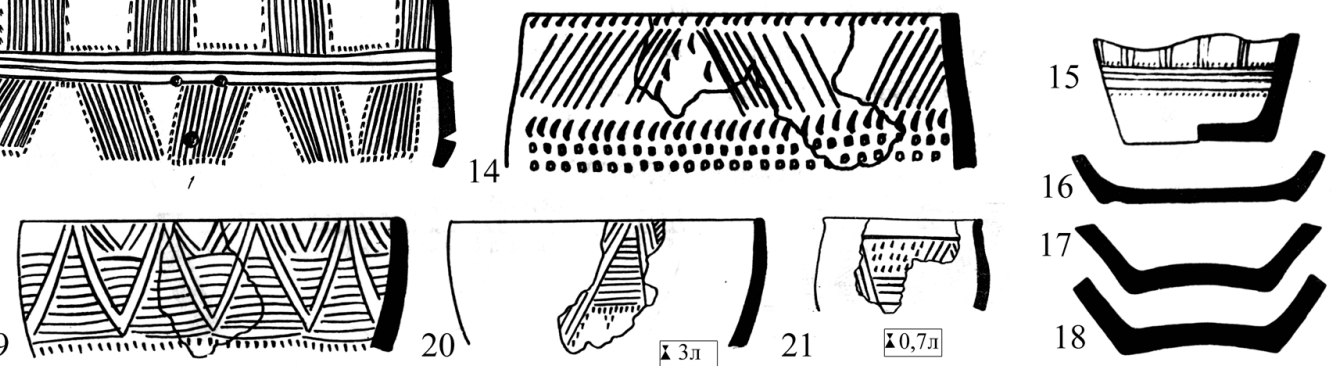

22
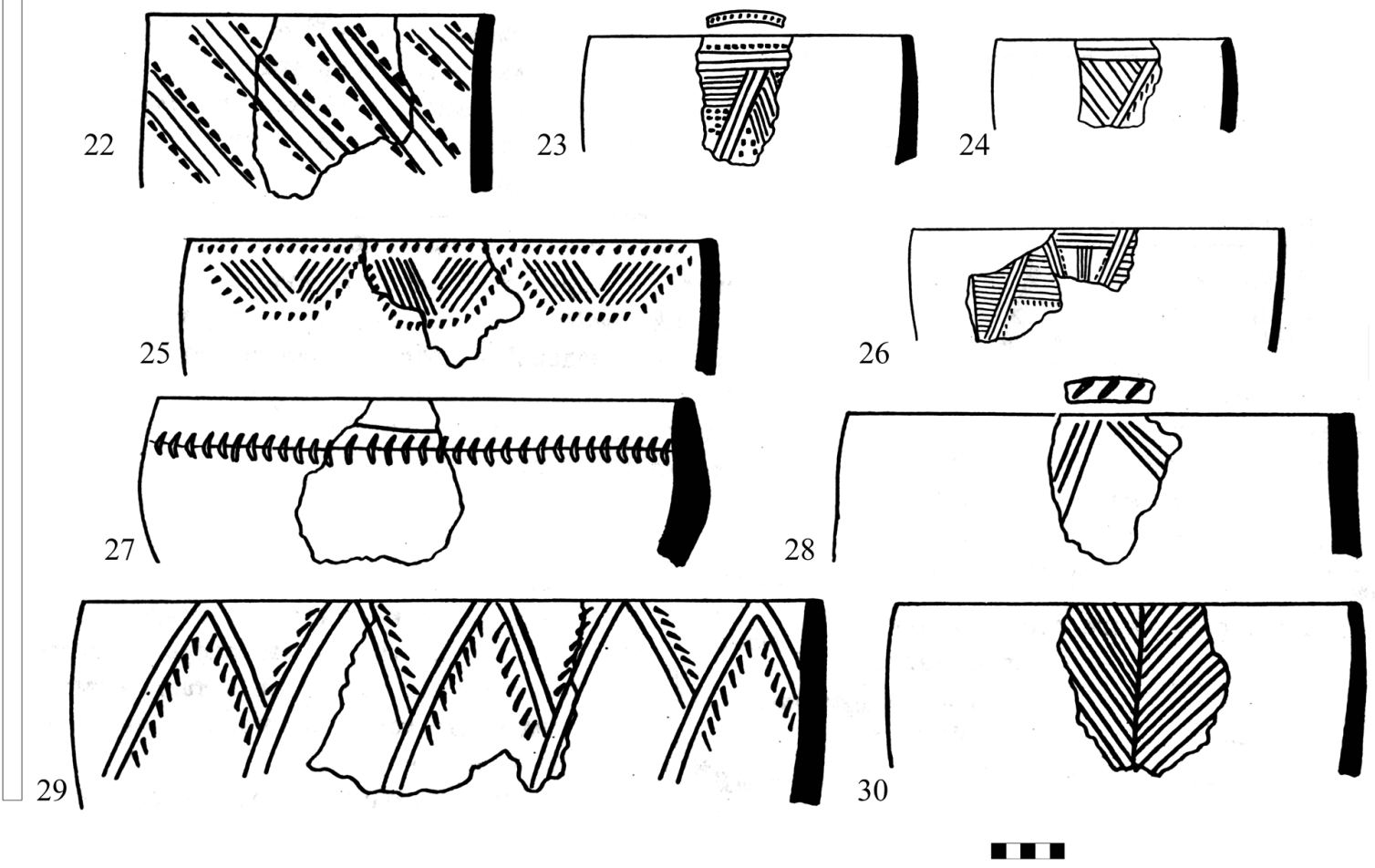

Fig. 3. Pottery from the Lower Volga region: 1-2 Kugat IV; 3 Kulagaisi; 4-5 Tu-Buzgu-Huduk I; 6-30 Kairshak (after Vybornov 2008). 
1990; 1995; Levkovskaya 1995; Spiridonova, Aleshinskaya 1999; Mamonov 2006). The forest steppe zone transformed into the forest zone only recently. There was steppe, with patches of forest inside river valleys. Naturally, in dry periods the forest zone with woodlands and rich food resources was a favourable area for people from more southerly regions (Arslanov et al. 2009; Vybornov 2011).

\section{The forest zone of Eastern Europe}

In the forest zone of Eastern Europe generally only one component of the Neolithic was distributed, namely pottery, the characteristics of which allow to us to make conclusions about the process of neolithisation in this part of Europe.

\section{The Dvina-Lovat River region}

The detailed studies of artefact assemblages of the Dvina River Region allow us to distinguish several ceramic traditions that were defined as 'ceramic phases' (see Miklayev 1994).

Lakes in the Dvina-Lovat River region were mainly formed at the end of the Pleistocene - beginning of the Holocene within fluvioglacial and moraine depressions after the recession of the Late Würm stage ice-sheet. The further development of the lake systems relates to the humid period, when most of them were transformed into peat-bogs in the Late Holocene (Davidova 1992). However, some authors (Miettinen 2002; Lak 1975) argue that the tectonic processes of the Fennoscandian shield had more influence on the development of the drainage network on the north-western Russian plateau and the water fluctuations in the lake basins than climatic changes during the Holocene.

At the beginning of the Holocene, the Serteya valley consisted of large and deep lakes with steep slopes. More than 38 early Neolithic sites have been found in this region (Fig. 1) (Mazurkevich et al. 2012). The Early Neolithic Serteya culture includes ceramic phases ' $a$ ', ' $b$ ', and ' $b-1$ '. Other cultural traditions comprise the ceramic phases ' $a-1$ ', 'c-1' and also 'a-2', and 'b-2' (Mazurkevich et al. 2008) (Fig. 5).

Ceramics from the ' $a-1$ ' phase (Fig. 5) were made from clay tempered with sand and grog. The coil technique was used to make the pottery, which consisted of small circular coils. Traces of scratching treatment were visible both on the outer and inner surfaces of vessels. There are sherds with smoothed and polished surfaces. Ceramics of this type has no decoration. The pots are open or straight, with small

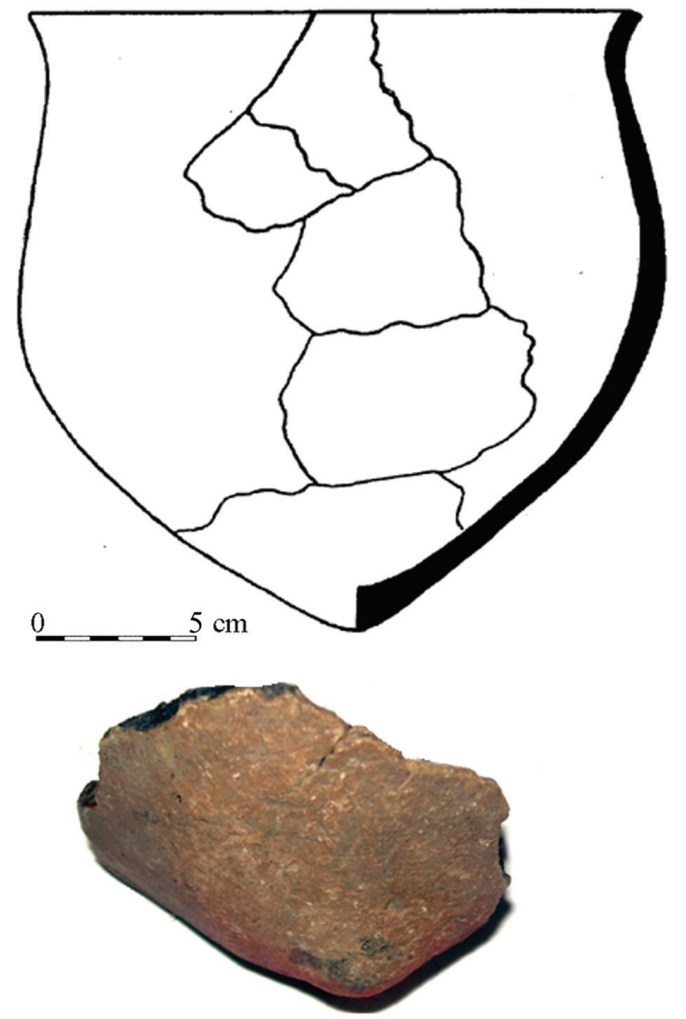

Fig. 4. 'Elshanian type' pottery from the site Chekalino at 8760-8000 calBP (after Vybornov et al. 2010).

cambered flat edges, similar to a cylindrical form. This type of pottery has analogues with undecorated vessels from the lowest layers of the Rakushechny Yar site.

The radiocarbon date on food crust of ceramic type 'a-1' from Serteya XIV site falls within the interval between 9520-9270 calBP; due to the reservoir effect, this date is probably too old $\left(\delta^{13} \mathrm{C}\right.$ in food crust is -33.8\%o) (Fischer, Heinemeier 2003). Nevertheless, it falls into the earliest typological interval of ceramic tradition (see more detail in Mazurkevich et al. 2013). Due to the proposed correction based on modern sample dating (Kulkova et al. 2014) it can be attributed to the beginning of the $9^{\text {th }}$ millennium calBP; the lowest cultural layers from the Rakushechny Yar site also match this date.

Another ceramic type relates to phase 'a' (Fig. 5). This type of pottery was formed from clay tempered with sand and grog, or from silt clay with organic inclusions without temper. The coil technique was used for moulding. The outer and inner surfaces were treated by scratching and then smoothed. This pottery was decorated with incisions and has analogues with ceramics from sites in the Low Volga River basin and in the Middle and Upper Don River basin. 


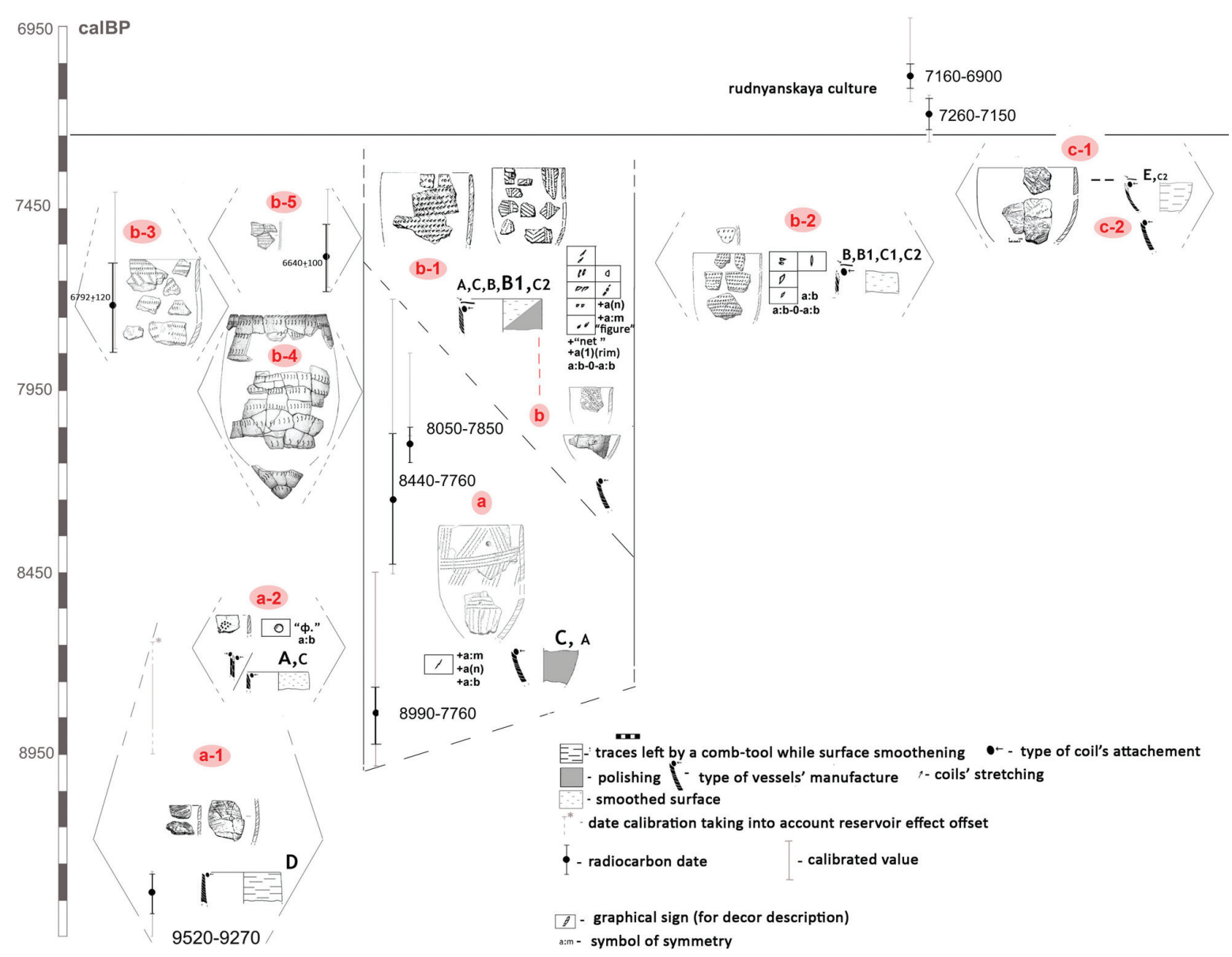

Fig. 5. Types of Early Neolithic pottery from the Serteya River basin.

The radiocarbon date of wood from the layer with ceramic type of phase ' $a$ ' is $8400-7760$ calBP (Timofeev et al. 2004) (Fig. 5). The age of the food crust on pottery from Rudnya Serteya site is 8990-8500 caBP. The cultural tradition represented by ceramic phase ' $a-2$ ', which is similar to Elshanian cultural traditions, can be dated to the same time. The ceramic tradition of local phase ' $b$ ' was formed on the base of ceramic phase 'a' between $c$. 8200-7900 calBP (Mazurkevich et al. 2013).

After $c .9450$ calBP, the water level fell in the Serteya valley lakes. The regression minimum was dated to $c .8550$ calBP. This was quite a warm period, but the climate remained dry. The bio-productivity of the lakes decreased. Data shows a decrease in population during this period (Mazurkevich et al. 2009). Paleogeographical studies indicate that there was a short period of cooler and drier climate beginning at $c$. 8200 calBP, which coincided with the rapid regression of lakes in the Serteya valley due to tectonic processes in Fennoscandia and the transgression of the Baltic Sea. This caused an increase in the lake's bio-productivity, as well as strengthening the anthropogenic influence on the lake system. The data pro- vides evidence of population growth. Thus, the ' $a-1$ ' and ' $a$ ' phases of the Serteya tradition began earlier than 8200 calBP, and further pottery groups of the phases ' $\mathrm{a}-2$ ' and ' $\mathrm{b}$ ' were formed (Mazurkevich et al. 2012; Mazurkevich, Dolbunova 2012; Mazurkevich et al. 2013).

\section{The Upper Volga River region}

According to various studies (Krainov, Khotinsky 1977; Zetlin 2008; Engovatova et al. 1998; Zaretskaya, Kostyleva 2008), the Neolithic culture of the Upper Volga River went through several stages. Undecorated ceramics constitute an element in the first stage of the Upper Volga culture. The data obtained show that various typological and technological styles can be differentiated within the undecorated pottery. Because of the complicated cultural processes present in the Volga-Oka basin, it is probable that similar ceramic groups from other sites of the Upper Volga River basin varied in the same way.

The earliest ceramics were cylindrical shape or with a partly closed rim (Fig. 6a). Only a few fragments of this type have been found. Similar examples of this type can be found in the pottery assemblage 
from the Rakushechny Yar site, the Dvina River basin sites (ceramic phase ' $a-1$ ') and the Valday culture ('type 1'). The radiocarbon dates of this type from the Zamostje 2 site obtained from the food crust on vessels fall into the long interval from 8600-7300 calBP (Meadows et al. 2015).

Another undecorated ceramic type from this collection is characterised by the use of coil stretching and molding with slabs. The clay paste contains shells. The outer and inner surfaces were treated by pebble smoothing and, as a result, coarse particles appear on the surface of the pottery walls (Fig. 6b). The shapes are either closed in the form of convergent cones or biconical. The radiocarbon dates of the food crusts on pottery fall into the period between 8200 7620 calBP (Meadows et al. 2015). This ceramic tradition is represented by different types of undecorated pottery which has analogues in assemblages from the Middle Volga River sites, the Valday site, and the Berezovaya Slobodka II-III site. The radiocarbon dates on the wood and charcoal from Berezovaya Slobodka II, III cultural layers with the finds of decorated and undecorated pottery fall into the interval between 8200-7980 calBP (Timofeev et al. 2004). Organic material (bone, peat) from layers containing Upper Volga pottery dated between 8200-7400 calBP (Lozovski 2003).

The Early Neolithic cultural layers containing the Upper-Volga ceramics were found in the Mesolithic layers of the sites at Ivanovskoe 3, 7, Sahtish 2a, Stanovoe 4, Ozerki 5 and Zamostje 2 (Kostyleva 2003).

For the period from $c .8400-8100$ calBP, some authors (Spiridonova, Aleshinskaya 1996; Aleshinskaya et al. 2001) have found the beginning of a reduction in water levels in the basin in this region on data from proxy indicators from peat-lake deposits. This process is connected with aridisation, mostly in the steppe and forest-steppe zones. Complete aridisation occurred at $c .8100$ calBP, which the authors suggest marked the natural transition from the Mesolithic to Neolithic in central Russia.

The appearance of Neolithic traditions among Mesolithic hunter-gatherers can be connected with migration of Neolithic farmers. Environmental factors were probably among the causes: the transition from the Mesolithic to the Neolithic (at $c .8200$ calBP) was characterised by complete aridisation not only in the steppe and forest-steppe zones, but also in the forest zones in Eastern Europe. These changes have been recorded in the pollen spectra for various parts of
Eastern Europe (Spiridonova, Aleshinskaya 1999). As noted by Elena Kostyleva (2003), migration did not include the whole population, but instead could have been in the form of small groups dispersing from the southern to northern regions.

\section{Discussion and conclusion}

At around 8200 calBP cold and dry climatic conditions were present in the Dvina-Lovat basin and the Upper Volga river region. These cold and dry conditions were an abrupt event that occurred in many areas of Eastern and Western Europe, as well as in the Middle East (Kofler et al. 2005; Magny 2003; Mayevsky et al. 2004, Aleshinskaya, Spiridonova 1999). A fall in river and lake water levels caused significant environmental transformations, provoking widespread migration (Mazurkevich et al. 2013). The high water level in the lakes of Dvina-Lovat basin, related to isostatic processes in the Baltic Sea, was one of the factors that attracted people in this area from the dry regions of the centre and south of the East European Plain (Kulkova et al. 2015).

The earliest Neolithic pottery appeared in the period from 9500 to 8950 calBP. This is the undecorated pottery found at various sites in Eastern Europe (Mazurkevich, Dolbunova 2012; Mazurkevich et al. 2013) including at Serteya XIV (Dniepr-Dvina region, phase ' $a-1$ '), Rakushechny Yar (Low Don River, bottom layers), and later, at the Zamostje 2 (Upper Volga region, types ' 4 ' and '7') sites.

In the period from 8950 to 8200 calBP, ceramics decorated with a retreating incised style have been found at North Caspian sites (Vybornov et al. 2012) (Kairshak III site, Kizilkhak, Varfolomeevka (layer 3), Kugat IV), in the Low Volga region, and in the DneprDvina basin (Rudnja Serteya, phase 'a'). At almost the same time, $c .8200$ calBP, the ceramic types 'b' and ' $a-2$ ' appeared in the Dvina-Lovat basin.

Pottery decorated with retreating incised style and with impressions in the period between 8200-7350 calBP was found at North Caspian sites and in the Low Volga region (including at sites such as Kairshak I and III, Djangar - layer 3, Varfolomeevka layer 2B), in the Middle Volga region (II Sherbetskaya), the Dniepr-Dvina region (Serteya $X$ - phase ' $a$ '), Upper Volga region (Sakhtysh 2a, Zamostie 2), Sukhona River region (Berezovaya Slobodka II-III), and other regions of Eastern Europe. During the period from 7950 to 7350 calBP, new types of undecorated pottery also appeared at several of these sites. 


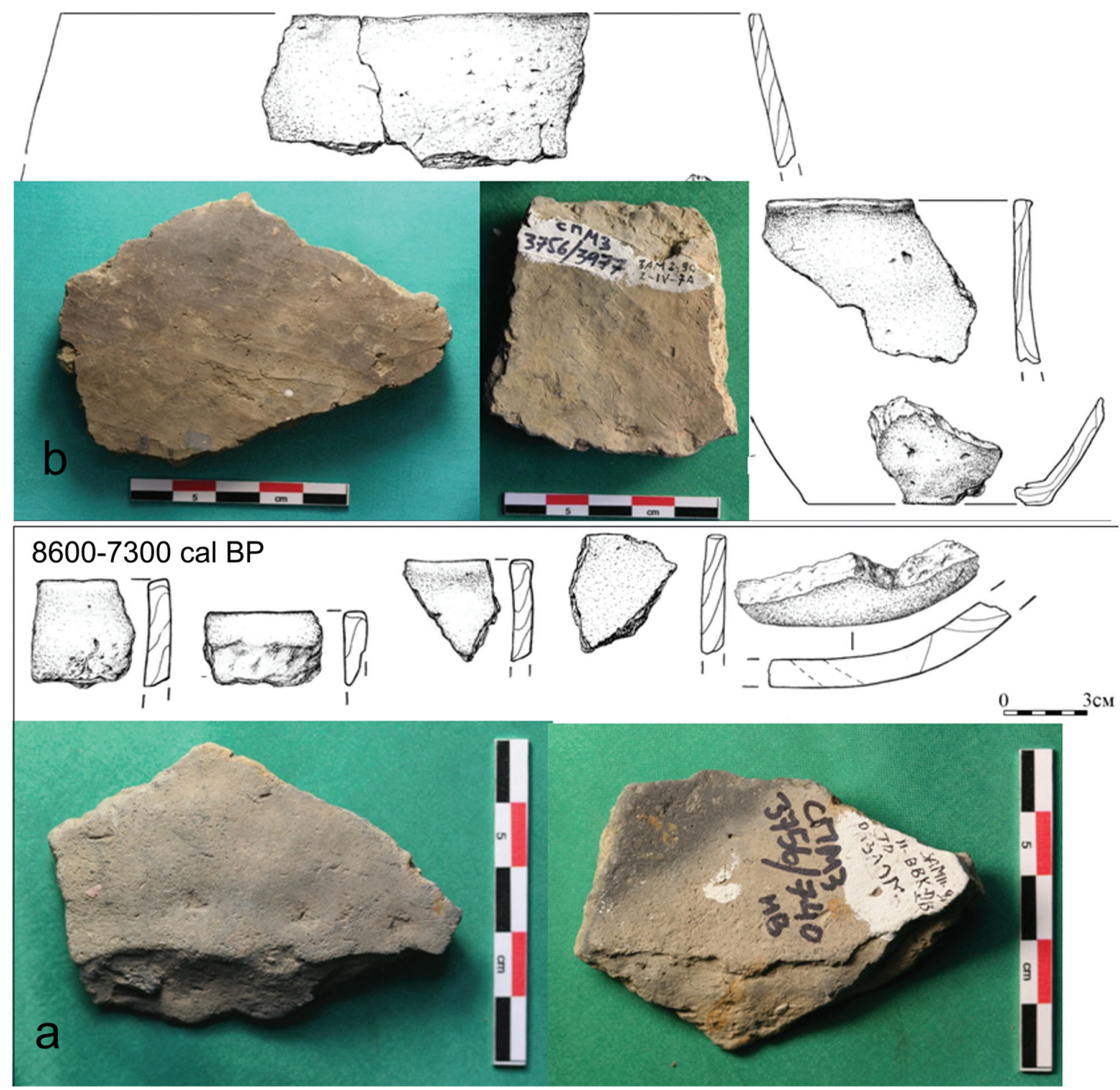

Fig. 6. a - Typology of 'type 1' undecorated Early Neolithic ceramics from site the Zamostje 2 at 82007620 calBP; b - typology of 'type 2' undecorated Early Neolithic ceramics from Zamostje 2.

The radiocarbon dates show the very fast propagation of the pottery within groups of local Mesolithic people in Eastern Europe (Belanovskaya, Timofeev 2003). There is a 'paradox of speed' in the spread of pottery. Both the appearance of Neolithic traditions at primary sites and the spread of pottery to other regions occurred during a short time. The migrants bearing ceramic traditions probably moved along the main waterways of Eastern Europe in meridional directions. At the same time, the river currents in latitudinal directions became natural barriers to the distribution of earliest pottery traditions, according to the distribution of early Neolithic sites (Dolukha$n o v$ et al. 2009a). These sites where pottery traditions were newly established, 'small islands of innovations', were secondary centres from which ceramic traditions spread among local Mesolithic groups (during the second half of $9^{\text {th }}$ and in the beginning of $8^{\text {th }}$ millenium BP). The ceramic traditions remained the same for a long time and, therefore, pottery from different periods has very similar typological characteristics (Mazurkevich et al. 2006). A small population occupied ecological niches as poor soil fertility, long winters and abundant terrestrial and water food resources were features of most of Eastern Europe (Dolukhanov et al. 2009b).

The most drastic climatic changes connected with the global climatic fluctuations were reflected in the distribution of different cultural traditions. The main migrations were probably from regions with the worst environment, in which the biomass had 
decreased, to regions with more favourable environmental conditions. Some evidence can be traced on the basis of the ceramic traditions at sites in the steppe, forest-steppe, and the forest zones of Eastern Europe. In the period of sharp climatic deterioration, ancient groups of people began to relocate. The density of population and settlements of different groups of people increased in certain micro-regions, as a rule with a more favourable environment. The most cold and dry climatic event occurred $c .8200 \mathrm{calBP}$, which influenced the reduction of water and food resources in the steppe and forest-steppe zones of Eastern Europe. In the forest zone, these changes were less clear. The transgressions in the Baltic Sea and inner lake basins connected by a hydrological network in regions such as the Dvina-Lovat basin, which were rich in natural resources, were one of the causes that attracted people in this period. Groups with different cultural traditions interacted, and exchanged experience and technologies. These groups arrived in several places in Eastern Europe. Different stylistic types of pottery dated to the same period can be found at one site. We can suggest that people of different cultures occupied the most favourable places at the same time during the period of climatic dete- rioration, for example, in the migration from the steppe and forest steppe zones to the forest zone.

The analysis allows us to consider impulses in the development of human groups in the period of the climatic cold event at 8200 calBP. In the drastic cooling and arid event population density was redistributed, and settlements were consolidated in places favourable for survival. The appearance of ceramic traditions among Mesolithic groups in Eastern Europe illustrates this event: this was a distribution of technology from less favourable to more favourable places. The 'primary centres' of neolithisation emerged in the Eastern Europe territory before the climatic cold event, but the appearance of pottery traditions at secondary centres began in the same period. Local Mesolithic people accepted only pottery technology, while hunting and gathering remained their main form of subsistence in the forest zones for a long time.

\section{ACKNOWLEDGEMENTS}

This study is supported by the Russian Found for Basic Research (RFBR), projects - 13-06-12057-ofi-m, 11-06-00090-a.

\section{References}

Adger N. W., Barnett J., Brown K., Marshall N. and O'Brien K. 2012. Cultural dimensions of climate change impacts and adaptation. Nature Climate Change 3: 112-117.

Alley R. B, Ágústsdóttir A. M. 2005. The 8k event: cause and consequences of a major Holocene abrupt climate change. Quaternary Science Reviews 24: 1123-1149.

Aleshinskaya A., Lavrushin Yu. A. and Spiridonova E. A. 2001. Geologo-paleoecologicheskie sobitiya golozena $i$ sreda obitaniya drevnego cheloveka $v$ raione arheologicheskogo pamyatnika Zamostie 2 (Geological-paleoenvironment events of the Holocene and environment of ancient people in district of Zamostie 2 site). Kamenny vek Evropeyskih ravnin. Sergiev-Posad. (in Russian)

Arslanov Kh. A., Savel'eva L. A., Dzinoridze E. N., Mazurkevich A. N. and Dolukhanov P. M. 2009. The Holocene environments in North-Western and Central Russia. In P. M. Dolukhanov, G. R. Sarson and A. M. Shukurov (eds.), The East European Plain on the Eve of Agriculture. British Archaeological Reports IS 1964. Archaeopress. Oxford: $109-123$.
Baldia M. 0. 2013. Breaking Unnatural Barriers: Comparative Archaeology, Climate, and Culture Change in Central and Northern Europe (6100-2700 BC). In M. 0. Baldia, T. K. Perttula and Frink D. S. (eds.), Comparative Archaeology and Paleoclimatology: Sociocultural responses to a changing World. British Archaeological Reports IS 2456. Archaeopress. Oxford: 175-240.

Bánffy E., Sümegi P. 2012. The early Neolithic agro-ecological barrier in the Carpathian Basin: a zone for interaction. In P. Anreiter, E. Bánffy, L. Bartosiewicz, W. Meid and C. Metzner-Nebelsick (eds.), Archaeological, cultural and linguistic heritage: Festschrift for Erzsébet Jerem in honour of her $70^{\text {th }}$ birthday. Archaeolingua. Budapest: 5769.

Barber D. C., Dyke A., Hillaire-Marcel C., Jennings A. E., Andrews J. T., Kerwin M. W., Bilodeau G., McNeely R., Southon J., Morehead M. D. and Gagnon J.-M. 1999. Forcing of the cold event of 8,200 years ago by catastrophic drainage of Laurentide lakes. Nature 400: 344-348.

Bassetti M., Cusinato A., Dalmeri G., Hrozny Kompatscher M. and Wierer U. 2009. Updating on the Final Palaeoli- 
thic-Mesolithic transition in Trentino (NE Italy). Preistoria Alpina 44: 121-135.

Belanovskaya T. D. 1995. Iz drevneishego proshlogo Nizhnego Podonja: Poselenie vremeni neolita-eneolita Rakushechny Yar (From the most ancient of past of the Low Don River region: the settlement Rakushechny Yar of Neolithic-Eneolithic period). St. Petersburg University. Saint Petersburg. (in Russian)

Belanovskaya T. D., Timofeev V. I. 2003. Mnogosloinoe poselenie Rakushechny Yar (Nizhnee Podonie) i problemi neolitizazii Vostochnoy Evropi. In V. I. Timofeev (ed.), Neolit-Eneolit yuga i neolit severa Vostiochnoi Evropi. Novie materiali, issledovaniya, problemi neolitizacii regionov. Rossiyskaya Akademiya Nauk. Institut materialnoy kulturi. St. Petersburg: 14-21. (in Russian)

Belanovskaya T. D., Timofeev V. I., Zaitseva G. I., Kovalukh N. N. and Skripkin V. V. 2003. Novie radiouglerodnie dati neoliticheskih sloev mnogosloinogo poseleniya Rakushechny Yar. Drevnosti Podviniya: istoricheskii aspect. Po materialam kruglovo stola, posvjaschenogo pamjati A. M. Miklyaeva, 6.-8. oktyabrya 1999. Izdateljstvo Gos. Ermitaža. St. Petersburgh: 134-139. (in Russian)

Bell M., Walker M. J. C. 2005. Late Quaternary Environmental Change: Physical and Human Perspectives. Pearson-Prentice Hall. Harlow.

Berger J.F., Guilaine J. 2009. The 8200 cal BP abrupt environmental change and the Neolithic transition: A Mediterranean perspective. Quaternary International 200: 31-49.

Berglund B. 2003. Human impact and climate changes synchronous events and a causal link? Quaternary International 105: 7-12.

Binford L. R. 2001. Constructing Frames of Reference. An Analytical Method for Archaeological Theory Building Using Ethnographic and Environmental Data Sets. University of California Press. Berkeley, Los Angeles, London.

Bond G., Showers W., Cheseby M., Lotti R., Almasi P., deMenocal P., Priore P., Cullen H., Hajdas I. and Bonani G. 1997. A pervasive millenial-scale cycle in North Atlantic Holocene and glacial climates. Science 278: 1257-1266.

Bond G., Kromer B., Beer J., Muscheler R., Evans M. N., Showers W., Hoffmann S., Lotti-Bond R., Hajdas I. and Bonani G. 2001. Persistent solar influence on North Atlantic climate during the Holocene. Science 294: 2130-2136.

Brooks N. 2006. Cultural responses to aridity in the Middle Holocene and increased social complexity. Quaternary International 151: 29-49.
Brooks N., Chiapello I., Dilernia S., Drake N., Legrand M., Moulin C. and Prospero J. 2005. The Climate-Environment-Society Nexus in the Sahara from Prehistoric Times to the Present Day. The Journal of North African Studies 10(3-4): 253-292.

Budja M. 2007. The 8200 cal BP 'climate event' and the process of neolithisation in south eastern Europe. Documenta Praehistorica 36: 191-201.

2013. Neolithic pots and potters in Europe: the end of 'demic diffusion'. Documenta Praehistorica 40: 3955 .

Brunet F., Khudhzanazarov M. and Hoshimov H. 2012. Nouvelles donnessur la chronologie de la culture de Kelteminar en Ouzbekistan. In A. Berdimuradov (ed.), The History of Material Culture of Uzbekistan. URFA Press. Samarkand: 118-124.

Bush A. B. G. 2005. $\mathrm{CO}_{2} / \mathrm{H}_{2} \mathrm{O}$ and orbitally driven climate variability over central Asia through the Holocene. Quaternary International 136: 15-23.

Carlson A. E., Clark P. U., Haley B. A. and Klinkhammer G. P. 2009. Routing of western Canadian Plains runoff during the $8.2 \mathrm{ka}$ cold event. Geophysical Research Letters 36: L14704, doi:10.1029/2009GL038778.

Cilingiroğlu C. 2005. The concept of "Neolithic package": considering its meaning and applicability. Documenta Praehistorica 32: 1-13.

Daley T. J., Thomas E. R., Holmes J. A., Street-Perrott F. A., Chapman M. R., Tindall J. C., Valdes P. J., Loader N. J., Marshall J. D., Wolff E. V., Hopley P. J., Atkinson T., Barber K. E., Fisher E. H., Robertson I., Hughes P. D. M. and Roberts C. N. 2011. The $8200 \mathrm{yr}$ BP cold event in stable isotope records from the North Atlantic region. Global and Planetary Change 79: 288-302.

Davidova N. N. (ed.) 1992. Istoriya ozer Vostocho-Evropeyskoi ravnini. (History of Lakes in East European Plain). Nauka. Moskva.

Dincauze D. F. 2000. Environmental archaeology: principles and practice. Cambridge University Press. Cambridge.

Dolukhanov P. M., Shukurov A., Davison K., Sarson G., Gerasimenko N. P., Pashkevich G. A., Vybornov A. A., Kovalyukh N. N., Skripkin V. V., Zaitseva G. I. and Sapelko T. V. 2009a. The spread of the Neolithic in the South East European Plain: radiocarbon chronology, subsistence, and environment. Radiocarbon 51(2): 783-793.

Dolukhanov P. M., Mazurkievich A. M. and Shukurov A. M. 2009b. Early pottery makers in Eastern Europe: cen- 
ters of origin, subsistence and dispersal. In P. Jordan, M. Zvelebil (eds.), Ceramics before Farming: The Dispersal of Pottery among Prehistoric Eurasian Hunter-Gatherers. Left Coast Press. Walnut Creek: 237-253.

Duigan C. A., Birks H. H. 2000. The late-glacial and early Holocene palaeoecology of cladoceran microfossil assemblages at Kråkenes, western Norway, with a quantitative reconstruction of temperature changes. Journal of Paleolimnology 23: 67-76.

Engovatova A. V., Zhilin M. G. and Spiridonova E. A. 1998. Khronologiya verkhnevolzhskoi ranneneoliticheskoi kultury (po materialam mnogosloinykh pamyatnikov VolgoOkskogo mezhdurechya). Rossiiskaya Arkheologiya 2: 11-21.

Fischer A., Heinemeier J. 2003. Freshwater reservoir effect in ${ }^{14} \mathrm{C}$ dates of food residue on pottery. Radiocarbon 45: 449-466.

Gronenborn D. 2009. Climate fluctuations and trajectories to complexity in the Neolithic: towards a theory. Documenta Praehistorica 36: 97-110.

Hassan F. A. 2002. Palaeoclimate, food and cultural change in Africa: an overview. In F. A. Hassan (ed.), Droughts, Food and Culture: Ecological Change and Food Security in Africa's Later Prehistory. Kluwer Academic/Plenum Publisher. New York: 11-26.

Hofmann W. 2000: Response of the chydorid faunas to rapid climatic changes in four alpine lakes at different altitudes. Palaeogeography, Palaeoclimatology, Palaeoeco$\log$ 159: 281-292.

Hoffman J. S., Carlson A. E., Winsor K., Klinkhammer G. P., LeGrande A. N., Andrews J. T. and Strasser J. C. 2012. Linking the $8.2 \mathrm{ka}$ event and its freshwater forcing in the Labrador Sea. Geophysical Research Letters 39: L18703, doi:10.1029/2012GL053047.

Holl A. F. C. 1998. Livestock husbandry, patoralism, and territoriality: the West African Record.Journal of Anthropological Archaeology 17: 143-165.

Goosse H., Renssen H., Selten F. M., Haarsma R. J. and Opsteegh J. D. 2002. Potential causes of abrupt climate events: a numerical study with a three-dimensional climate model. Geophysical Research Letters 29: 7-1 - 7-4.

Kelly R. L. 1995. The Foraging Spectrum: Diversityin Hunter-Gatherer Lifeways. Smithsonian Institution Press. Washington and London.

Kobashi T., Severinghaus J. P., Brook E. J., Barnola J.-M. and Grachev A. M. 2007. Precise timing and characteriza- tion ofabrupt climate change 8200 years ago from air trapped in polar ice. Quaternary Science Reviews 26: 12121222.

Kofler W., Krapf V., Oberhuber W. and Bortenschlager S. 2005. Vegetation responses to the $8200 \mathrm{cal}$. BP cold event and to long-term climatic changes in the Eastern Alps: possible influence of solar activity and North Atlantic freshwater pulses. The Holocene 15(6): 779-788.

Kostyleva E. L. 2003. Osnovnie voprosi neolitizazii zentra Russkoi ravnini (osobennosti neolitizazii lesnoi zoni). In V. I. Timofeev (ed.), Neolit-Eneolit yuga i neolit severa Vostochnoi Evropi. Novie materiali, issledovaniya, problemi neolitizacii regionov. Rossiyskaya Akademiya Nauk. Institut materialnoy kulturi. St. Petersburg: 213-218. (in Russian)

Kotova N. S. 2002. Neolitizatsiya Ukraini. Shlakh. Lugansk. (in Russian)

Krainov D. A., Khotinsky N. A. 1977. Verhnevolzhskaya ranneneoliticheskaya kultura. Sovetskaya Arheologiya 2: 42-67. (in Russian)

Kulkova M. A., Mazurkevich A. N., Nesterov E. M. and Sinai M. Y 2015. The analysis of stable isotopes and radiocarbon dating of artefacts of the Neolithic site Serteya II (Dvina-Lovat' interĐuve). In the Institute for History of Material Culture Russian academy of Science (ed.), Neolithic cultures of Eastern Europe: Chronology, Paleoecology and cultural traditions. Materials of the International Conference, dedicated to the $75^{\text {th }}$ anniversary of Victor Petrovich Tretyakov, May, 12-16, 2015. Russian Academy of Sciences. Institute of the History of Material Culture. St. Petersburg: 36-40.

Kulkova M., Mazurkevich A. and Gerasimov D. 2015. Stone Age archaeological sites and environmental changes during the Holocene in the NW region of Russia. In J. Harff, G. Bailey and F. Lüth (eds.), Geology and Archaeology: Submerged Landscapes of the Continental Shelf. Geological Society London. Special Publications 411. London: http://dx.doi.org/10.1144/SP411.8

Lak G. Z. 1975. Diatomovaya flora ozernih onlozhenii $v$ kotlovine Ladozhskogo ozera. Istoriya ozer v Golozene. (in Russian)

Lamb H. H. 1977. Climate: Present, Past and Future. Methuen. London.

1995. Climate, History and the Modern World. Methuen. London.

Lamy F., Kilian R., Arz H. W., Francois J. P., Kaiser J., Prange M. and Steinke T. 2010. Holocene changes in the posi- 
tion and intensity of the southern westerly wind belt. Nature Geoscience 3: 695-699.

Lavrushin Yu. A., Spiridonova E. A. 1990. Zakluchenie po rezultatam geologicheskogo $i$ palinologicheskogo $i z u-$ chenija stojanok Lebjazhinka IV i Chekalino IV v Samarskoi oblasti. Arkhiv archeologicheskoy laboratorii PGSGA. Samara 20. (in Russian)

Lavrushin Yu. A., Spiridonova E. A. 1995. Resultati paleomorfologicheskih issledovanii na stoyankah neolita-bronzi $\mathrm{v}$ basseine r. Samara. In Neolit $i$ eneolit yuga leso-stepi Volgo-Uralskogo mezhdurechya. Orenburg: 177-200. (in Russian)

Levkovskaya G. M. 1995. Zakluchenie po rezultatam sporovo-pilzivogo analiza obrazov iz razrezov stoyanok ivanovskogo mikrorayona na r. Tok. In Neolit i eneolit yuga leso-stepi Volgo-Uralskogo mezhdurechya. Orenburg: 173-176. (in Russian)

Li Y.-X., Tornqvist T. E., Nevitt J. M. and Kohl B. 2012. Synchronizing a sea-level jump, final Lake Agassiz drainage, and abrupt cooling 8200 years ago. Earth and Planetary Science Letters 315/316: 41-50.

Lozovski V. M. 2003. Perehod ot lesnogo mezolita k lesnomu neolitu v Volgo-Okskom mezhdurechie (po materialam stoyanki Zamostie 2). Neolit-Eneolit yuga i neolit severa Vostochnoi Evropi. Novie materiali, issledovaniya, problemi neolitizacii regionov. Rossiyskaya Akademiya Nauk. Institut materialnoy kulturi. St. Petersburg: 219-239. (in Russian)

Magny M., Begeot C., Guiot J. and Peyron 0. 2003. Contrasting patterns of hydrological changes in Europe in response to Holocene climate cooling phases. Quaternary Science Reviews 22: 1589-1596.

Mamonov A. E. 2006. Prirodnaya sreda v rannem neolite Samarskogo Zavolzhya i Orenburgskogo Priuraliay i adaptazionnii aspekt izucheniya Elshanskoy kulturi. In Archaeologicheskoe izuchenie Zentralnoy Rossii. LGPU. Lipezk: 93-95. (in Russian)

Manninen M. M. 2014. Culture, behavior, and the 8200 cal BP cold event. Organizational change and cultureenvironment dynamics in late Mesolithic Northern Fennoscandia. Monographs of the Archaeological Society of Finland 4. Helsinki: 190.

Mayewski P. A., Meeker L. D., Twickler M. S., Whitlow S., Yang Q., Lyons W. B. and Prentice M. 1997. Major features and forcing of high latitude northern hemisphere atmospheric circulation using a 110,000-year long glaciochemical series. Journal of Geophysical Research 102(C12): 26345-26366.
Mayewski P., Rohling E. E., Stager J. C., Karlén W., Maasch K. A., Meeker L. D., Mayerson E. A., Gasse F., van Kreveld S., Holmgren K., Lee-Thorp J., Rosqvist G., Rack F., Staubwasser M., Schneider R. R. and Steig E. J. 2004. Holocene climate variability. Quaternary Research 62(3): 243-255.

Mazurkevich A. N., Dolukhanov P. M., Shukurov A. M. and Zaitseva G. I. 2006. Pottery-making revolution in Northern Eurasia. In The Institute for History of Material Culture Russian academy of Science (ed.), Materials of International conference "Man and Environment in Pleistocene and Holocene: Evolution of Waterways and Early Settlement of Northern Europe". Russian Academy of Sciences. Institute of the History of Material Culture. St. Petersburg: 20.

Mazurkevich A. N., Kulkova M. A. and Dolbunova E. V. 2008. Osobennosti izgotovlenija ranneneoliticheskoy keramiki v Lovatsko-Dvinskom mezhdurechie. Acta Archaeologica Albaruthenica 8: 139-160. (in Russian)

Mazurkevich A. N., Korotkevich B. N., Dolukhanov P. M., Shukurov A. M, Arslanov Kh. A., Savel'eva L. A., Dzinoridze E. N., Kulkova M. A. and Zaitseva G. I. 2009. Climate subsistence and human movements in the Western Dvina - Lovat River Basins. Quaternary International 203 (1-2): 52-66.

Mazurkevich A. N., Dolbunova E. V. 2012. The most ancient pottery and Neolithisation of Eastern Europe. Fontes Archaeologici Posnanienses 48: 143-159.

Mazurkevich A. N., Kulkova M. A. and Savel'eva L. A. 2012. Geoarchaeological issues of the Upper Dnieper-Western Dvina river region (Western Russia): fieldtrip guide. Part II. Universum. Moscow-Smolensk.

Mazurkevich A. N., Dolbunova E. V. and Kukova M. A. 2013. Keramicheskie tradizii v rannem neolite Vostochnoi Evropi. In Rossiskii arheologicheskii ezhegodnik. St. Petersburg State University. St. Petersburg: 3-85. (in Russian)

Meadows J., Losovski V. M., Lozovskaya 0. V., Lubke H., Zaitceva G. I. and Kulkova M. A. 2015. Place of Zamostje 2 site pottery assemblage within the overall chronology of upper Volga-type pottery. In the Institute for History of Material Culture Russian academy of Science (ed.), Neolithic cultures of Eastern Europe: Chronology, Paleoeco$\log y$ and cultural traditions. Materials of the International Conference, dedicated to the $75^{\text {th }}$ anniversary of Victor Petrovich Tretyakov, May, 12-16, 2015. Russian Academy of Sciences. Institute of the History of Material Culture. St. Petersburg: 84-87.

Migowski C., Stein M., Prasad S., Negendank J. F. W. and Agnon A. 2006. Holocene climate variability and cultural 
evolution in the Near East from the Dead Sea sedimentary record. Quaternary Research 66(3): 421-431.

Miklyaev A. M. 1994. Kamennii-zheleznii vek v mezhdureche Zaoadnoy Dvini i Lavati. Peterburgskii arheologicheskii vestnik 9: 8-42. (in Russian)

Miettinen A. 2002. Relative Sea Level Changes in the Eastern Part of the Gulf of Finland during the Last 8000 Years. In Annales Academiae Scientiarum Fennicae. GeologicaGeographica 162. Finnish Academy of Science and Letters. Suomalainen Tiedeakatemia Helsinki: 2-10.

Morrill C., Jacobsen R. M. 2005. How widespread were climate anomalies 8200 years ago? Geophysical Research Letters 32: L19701, doi:10.1029/2005GL023536.

Morrill C., Anderson D. M., Bauer B. A., Buckner R. E., Gille P., Gross W. S., Hartman M. and Shah A. 2013. Proxy benchmarks for intercomparison of $8.2 \mathrm{ka}$ simulations. Climate of the Past 9: 423-432.

Mullins H. T., Halfman J. D. 2001. High-resolution seismic reflection evidence for middle Holocene environmental change, Owasco Lake, New York. Quaternary Research 55: 322-331.

Munoz S. E., Gajewski K. and Peros M. C. 2010. Synchronous environmental and cultural change in the prehistory of the northeastern United States. Proceedings of the $\mathrm{Na}$ tional Academy of Sciences of the United States of America 107(51): 22008-22013.

Özdoğan M. 2001. Redefining the Neolithic of Anatolia: A Critical Overview. In R. T. J. Cappers, S. Bottema (eds.), The Dawn of Farming in the Near East. Studies in Early Near Eastern Production. Subsistence and Environment 6: 155-161.

Rasmussen S. O., Vinther B. M., Clausen H. B. and Andersen K. K. 2007. Early Holocene climate oscillations recorded in three Greenland ice cores. Quaternary Science Reviews 26: 1907-1914.

Riede F. 2009. Climate and Demography in Early Prehistory: Using Calibrated ${ }^{14} \mathrm{C}$ Dates as Population Proxies. Human Biology 81(2): 309-337.

Robinson E., Van Strydonck M., Gelorini V. and Crombé P. 2013. Radiocarbon chronology and the correlation of hunter-gatherer sociocultural change with abrupt palaeoclimate change: the Middle Mesolithic in the Rhine-MeuseScheldt area of northwest Europe. Journal of Archaeological Science 40(1): 755-763.

Rohling E., Pälike H. 2005.Centennialscale climate cooling with a sudden cold event around 8,200 years ago. Nature 434: 975-979.
Sarmaja-Korjonen K., Seppä H. 2007. Abrupt and consistent responses of aquatic and terrestrial ecosystems to the 8200 cal. yr cold event: a lacustrine record from Lake Arapisto, Finland. The Holocene 17: 457.

Seppä H., Poska A. 2004. Holocene annual mean temperature changes in Estonia and their relationship to solar insolation and atmospheric circulation patterns. Quaternary Research 61: 22-31.

Seppä H., Birks H. J. B., Giesecke T., Hammarlund D., Alenius T., Antonsson K., Bjune A. E., Heikkilä M., MacDonald G. M., Ojala A. E. K., Telford R. J. and Veski S. 2007. Spatial structure of the $8200 \mathrm{cal} \mathrm{yr}$ BP event in northern Europe. Climate of the Past 3: 225-236.

Smolyaninov R. V. 2012. Ranny neolit Verkhnego Dona. In S. A. Vasil'ev (ed.), Mezolit i Neolit Vostochnoi Evropy: Khronologiya i Kulturnoe Vzaimodeistvie. Rossiyskaya Akademiya Nauk. Institut materialnoy kulturi. St. Petersburgb: 252-264. (in Russian)

Spiridonova E. A., Aleshinskaya A. S. 1999. Periodizaziya neolita-eneolita Evropeyskoi Rossii po dannim palinologicheskogo analisa. Rossiiskaya arheologiya 1: 23-33. (in Russian)

Staubwasser M., Weiss H. 2006. Holocene climate and cultural evolution in late prehistoric-early historic West Asia. Quaternary Research 66(3): 372-387.

Sümegi P., Kertèsz R. and Hertelendi E. 1998. Environmental change and human adaptation in the Carpathian Basin at the Late Glacial/Postglacial transition. In E. Jerem, T. Biró K. (eds.), Proceedings of the 31 International Symposium on Archaeometry. Archaeopress. BAR Central European Series 1. Archaeolingua. Budapest: 170-177.

Timofeev V. I., Zaitseva G. I., Dolukhanov P. M. and Shukurov A. M. 2004. Radiouglerodnaya Khronologiya Neolita Severnoi Evrazii. Teza. Saint Petersburg. (in Russian)

Tipping R., Bradley R., Sanders J., McCulloch R. and Wilson R. 2012. Moments of crisis: climate change in Scottish prehistory. Proceedings of the Society of Antiquaries of Scotland 142: 9-25.

Thomas E. R., Wolff E. W., Mulvaney R., Steffensen J. P., Johnsen S. J., Arrowsmith C., White J. C. W., Vaughn B. and Popp T. 2007. The $8.2 \mathrm{ka}$ event from Greenland ice cores. Quaternary Science Reviews 26: 70-81.

Tornqvist T. E., Hijma M. P. 2012. Links between early Holocene ice-sheet decay, sea-level rise and abrupt climate change. Nature Geoscience 5: 601-606. 
Turney C. S. M., Baillie M., Palmer J. and Brown D. 2006. Holocene climatic change and past Irish societal response. Journal of Archaeological Science 33: 34-38.

van Geel B., Bokovenko N. A., Burova N. D., Chugunov K. V., Dergachev V. A., Dirksen V. G., Kulkova M., Nagler A., Parzinger H., van der Plicht J., Vasiliev S. S. and Zaitseva G. I. 2004. Climate change and the expansion of the Scythian culture after $850 \mathrm{BC}$, a hypothesis. Journal of Archaeological Science 31: 1735-1742.

Vasilieva I. N., Vibornov A. A. 2013. O neoliticheskoi goncharnoi tekhnologii Nizhnego Prikamja i vremeni rasprostranenija drevneishih keramicheskih tradizii. Povolzhskaya Archaeologija 1(3): 60-87. (in Russian)

Veski S., Seppä H. and Ojala A. E. K. 2004. Cold event at $8200 \mathrm{yr}$ B.P. recorded in annually laminated lake sediments in Eastern Europe. Geology 32: 681-84.

Vinther B. M., Andersen K. K., Jones P. D., Briffa K. R. and Cappelen J. 2006. Extending Greenland temperature records into the late eighteenth century. Journal of Geophysical Research111: D11105, doi:10.1029/2005JD00 6810.

Vybornov A. A. 2008a. Neolit Volgo-Kamya. Samarskii Gosudarstvennyi Pedagogicheskii Universitet. Samara. (in Russian)

2008b. Korrektirovka radiouglerodnoy khronologii neolita nizhnego Povolzhja. Izvestija Samarskogo nauchnogo centra Rossiiskoi Akademii nauk 10(4): 1249-1255. (in Russian)

2010. On the correlation of natural and cultural processes in the Neolithic - Volga-Kama area. Documenta Praehistorica 37: 293-297.

2011. Time and palaeoenvironment in the Neolithisation of the Povolzhye forest-steppe. Documenta Praehistorica 38: 267-74.

Vybornov A., Zaitseva G., Kovaliukh N., Kulkova M., Possnert G. and Skripkin V. 2012. Chronological problems with neolithization of the northern Caspian Sea area and the forest-steppe Povolzhye region. Radiocarbon 54(34): 795-799.
Walker M. J. C., Berkelhammer M., Björck S., Cwynar L. C., Fisher D. A., Long A. J., Lowe J. J., Newnham R. M., Rasmussen S. 0. and Weiss H. 2012. Formal subdivision of the Holocene Series/Epoch: a Discussion Paper by a Working Group of INTIMATE (Integration ofice-core, marine and terrestrial records) and the Subcommission on Quaternary Stratigraphy (International Commission on Stratigraphy). Journal of Quaternary Science 27(7): 649-659.

Wendorf F., Shild R. 1998. Nabta Playa and its role in Northeastern African Prehistory. Journal of Anthropological Archaeology 17: 97-123.

Weninger B., Alram-Stern E., Bauer E., Clare L., Danzeglocke U., Jöris O., Kubatzki C., Rollefson G., Todorova H. and van Andel T. 2006. Climate forcing due to the 8200 cal yr BP event observed at Early Neolithic sites in the eastern Mediterranean. Quaternary Research 66: 401420.

Williams J. W., Post D. M., Cwynar L. C., Lotter A. F. and Levesque A. J. 2002. Rapid and widespread vegetation responses to past climate change in the North Atlantic region. Geology 30: 971-74.

Wiersma A. P., Renssen H. 2006. Model-data comparison for the $8.2 \mathrm{ka}$ B.P. event: confirmation of a forcing mechanism by catastrophic drainage of Laurentide lakes. Quaternary Science Reviews 25: 63-88.

Yudin A. I. 2000. Kulturnie kontakti i svyazi naseleniya Nizhnego Povolzhja v neoliticheskoe vremja. Nizhnevolzhskii archeologicheskii vestnik 3: 41-57. (in Russian)

Zaretskaya N. E., Kostyleva E. L. 2008. Radiouglerodnaya khronologiya nachalnogo etapa verkhnevolzhskoi ranneneoliticheskoi kultury. Rossiiskaya Arkheologiya 1: 514. (in Russian)

Zetlin Yu. B. 2008. Neolit centra Russkoi ravnini. Ornamentaciya keramiki i metodika periodizazii kultur. Russkaja Akademia Nauk. Tula. (in Russian)

Zvelebil M. 1998. What's in a name: The Mesolithic, the Neolithic and Social Change at the Mesolithic-Neolithic Transition. In M. Edmonds, C. Richards (eds.), Understanding the Neolithic of North-western Europe. Routledge. London: 1-35. 